\title{
Federal government tightens live-in caregiver regulations
}

$\mathrm{T}$ he federal government has moved to protect foreign workers who've been brought to Canada to be live-in caregivers by imposing tighter restrictions on employers.

The changes will include the creation of a public "blacklist" that will articulate the names of employers who fail to comply with minimum standards for working conditions. The blacklist will be posted on Citizenship and Immigration Canada's website.

As well, employers who fail to comply with regulations will be banned from hiring another live-in caregiver for a two-year period after they have been found to have breached conditions of the program. The changes became effective April 1.

The federal government is also proposing to undertake more rigorous assessments of the authenticity of employer offers.

There have been complaints in the past about abuse, poor working conditions and wages that fall below minimum wage standards, says Shokoofeh Moussavi, settlement and integration manager for the Calgary Immigrant Women's Association in Alberta.

"Some employers do not pay adequately, mistreat caregivers or have unrealistic expectations. There needs to be more accountability on both sides and more protection. Caregivers and employers need to be aware of their rights and responsibilities," she says.

The Live-in Caregiver Program has often faced criticism for leaving caregivers in precarious positions.

"Many caregivers work unpaid overtime because of their visible presence in the employer's home and fear of job loss," Terry Kalaw, a researcher at the School of Public Policy at Simon Fraser University in Burnaby, British Columbia, states in a report Employment Standards Violations and Live-in Caregivers' Characteristics in British Columbia (http://riim.metropolis.net/assets/uploads /files/wp/2010/WP10-08.pdf).

Moussavi says there is a need for

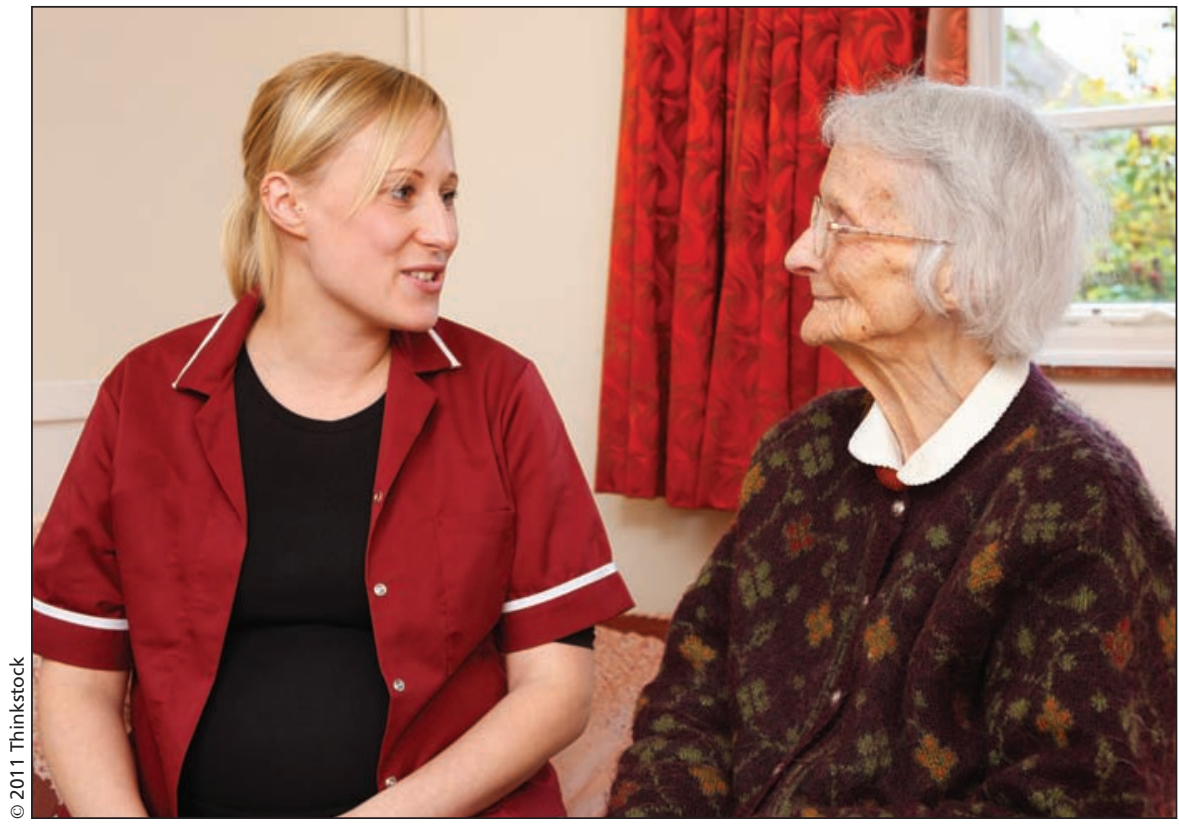

The demand for live-in caregivers is increasing as Canada's population ages.

greater responsibility among both employers and caregivers.

Established in 1992 to replace the Foreign Domestic Market program, the caregiver program allows Canadian employers to hire qualified temporary foreign workers to provide private home care for children, seniors or infirm relatives.

The demand for such live-in caregivers is increasing as Canada's population ages, says Marna Martin, chair of immigration and labour issues for the Canadian Coalition for In-Home Care. "We are seeing huge increases in senior care because baby boomers are getting to an age where they need care. If people can stay in their own home and if they are forgetful or have trouble with their vision, they feel better knowing that someone is living in the house with them."

To hire a caregiver, employers are required to apply to Human Resources and Skills Development Canada and Citizenship and Immigration Canada for a labour market opinion which assesses what impact hiring a temporary foreign worker will have on the Canadian labour market.
There is no cost for the assessment (except in Quebec, where the fee is \$177) which must conclude that the net effect will be positive or neutral. The application must include:

- completion of a foreign live-in caregiver application

- an employment contract

- appointment of representative form (if a third party reacts on behalf of the employer for the purposes of the labour market opinion)

- a description of the live-in caregiver bedroom

- a notice of assessment from the Canada Revenue Agency

- copies of advertisements

- proof of identity

- proof of age, if care is for children or seniors

- evidence of a medical disability certificate.

According to Annual Labour Market Opinion Statistics, in 2009, roughly 3\% or 20861 out of 643293 temporary foreign workers are live-in caregivers. Of those, 11211 are in Ontario and 4355 in British Columbia.

The program makes it easier for 
foreign workers to come to Canada, says Moussavi. "They can be processed (for permanent status) within a shorter time."

Caregivers are eligible to apply for permanent residency in Canada after working two years or an equivalent 3900 hours. The number of caregivers that have received permanent residency status has risen substantially over the past five years from 3547 in 2006 to 7661 in 2010.

To qualify for permanent residency, caregivers must secure a valid work permit and pass a medical examination. The applicant must also secure a positive labour market opinion from their Canadian employer, have a written contract with an employer, provide proof of education equivalent to a
Canadian secondary school degree, complete six months of caregiver training or have one year's experience as a full-time caregiver, and demonstrate proficiency in English or French.

For employers, the benefits of hiring a live-in caregiver are self-evident, says Martin. "A live-in caregiver allows for flexibility. Despite the fact that Johnny is sick, Mom doesn't have to take the day off and is not scrambling to find care."

Moussavi says live-in caregivers are also an affordable alternative to either day care or long-term care in nursing homes. "Daycare rates are much more expensive (and can be as high as) $\$ 1800$ per month for one child. The program offers the convenience of having someone at home."
But Martin notes that live-in caregivers are "not cheap child care." Caregivers must receive at least minimum wage and are typically provided room and board. Employers are also responsible for covering the costs of their caregiver's health insurance; workplace safety insurance; recruitment fees and travel costs from the caregivers' home country.

According to Human Resources and Skills Development Canada data, caregivers in $\mathrm{BC}$ are at the lowest end of the pay scale, receiving \$1280 monthly. By comparison, live-in caregivers in Nunavut receive the highest remuneration, averaging \$1760 monthly. Caroline George, Ottawa, Ont.

CMAJ 2011. DOI:10.1503/cmaj.109-3859 